\title{
TE்VŲ NUOMONĖS IR ŽINIŲ APIE KAUNO IKIMOKYKLINES ISTAIGAS LANKANČIŲ VAIKŲ JAUTRUMĄ MAISTUI VERTINIMAS
}

\author{
Rūta Ustinavičienė, Dalia Lukšienė, Ričardas Radišauskas, Lina Škẻmienė \\ Lietuvos sveikatos mokslu universiteto Medicinos akademija, \\ Visuomenés sveikatos fakultetas
}

Raktažodžiai: jautrumas maistui, maisto alergenai, tėvų žinios apie vaikų jautrumą maistui, šeimų gyvenimo kokybė.

\begin{abstract}
Santrauka
Maisto produktai gali sukelti ịvairių nepageidaujamų reakcijų, kurios vadinamos padidejusiu jautrumu maisto produktams. Tyrimo tikslas buvo įvertinti Kauno mieste ikimokyklines įstaigas lankančių vaikų jautrumo maistui dažnį bei tèvų (globèjų) nuomonę ir žinias apie vaikų jautrumą maistui. Anketinejje apklausoje dalyvavo 1143 vaikų tèvai. Nustatyta, kad jautrumo maistui dažnis ikimokyklinėse įstaigose siekè 15,2 proc., $(n=174)$, iš jų 98 (17,5 proc.) berniukai ir 76 (13,0 proc.) mergaitės. Mergaitès dažniau buvo jautrios šokoladui (61,8 proc.), citrusiniams vaisiams (50,0 proc.) ir pienui ( 43,4 proc.); tuo tarpu berniukai buvo labiau jautrūs pienui $(54,1$ proc.), šokoladui ( 45,9 proc.), kiaušiniams ( 39,8 proc.). Dažniausiai vaikams pasireiškè alerginès odos reakcijos ( 80,6 proc. berniukų ir 77,7 proc. mergaičiu), rečiau - sloga, čiaudulys (41,8 proc. berniukų ir 31,6 proc. mergaičių). Tẻvų nuomone, maisto alergijas lemia genetiniai veiksniai, mityba bei aplinkos tarša. Statistiškai reikšmingai daugiau žinių apie alergiją maistui ir anafilaksinio šoko galimybę turejjo aukštajį išsilavinimą ịgiję respondentai (atitinkamai ŠS $=2,73$ (95 proc. PI 1,25-6,31) ir ŠS $=2,83$ (95 proc. PI 1,984,95). Vaikų jautrumas maistui lėmé didžiosios dalies respondentų šeimų gyvenimo kokybę (82,2 proc.), siekiant užtikrinti tinkamą vaikų mitybą bei gydymą.
\end{abstract}

\section{Ivadas}

Pastaruoju metu alergija maistui tampa vis rimtesne sveikatos problema ir pasaulyje, ir Lietuvoje [1-7]. Problemos mastą rodo ir padidèjęs sveikatos priežiūros resursų poreikis, susijęs su šių ligų gydymu, pastebėtas daugelyje šalių $[1,8]$. Europos alergologų ir klinikinių imunologų akademijos teigimu, nuo alerginių ligų sukeltų simptomų kenčia 1 iš 4 Europos gyventojų, tai yra dažniausias lètinis susirgimas šio regiono šalyse [8-10]. Kiekvienoje šalyje yra skirtingos mitybos tradicijos, todèl alergijas sukelia skirtingi maisto produktai [1-8]. Liga neišvengiamai paveikia sergančiojo ir jam artimų žmonių gyvenimo kokybę bei buiti, taip pat didèja finansinè našta valstybei [11]. Dažniausiai nuo jautrumo maistui kenčia vaikai, tačiau tai smarkiai paveikia visos šeimos buiti ir gyvenimo kokybę [11-15]. Tam tikro alergizuojančio maisto produkto vengimas yra pats efektyviausias ir dažniausiai taikomas šios ligos gydymo būdas, jis reikalauja tėvų pastangų, žinių ir laiko. Todèl tėvai priversti keisti gyvenimo būdą, priprasti prie kylančių nepatogumų, nes privalo nuolat stebèti, ką vaikas valgo, ieškoti informacijos apie ligą, galimas kryžmines reakcijas [12-15]. Jautrių maistui vaikų šeimos susiduria su problemomis saugant savo vaikus nuo alergizuojančiu maisto medžiagų bei stengiantis išlaikyti racionalią jo mitybą, netrikdant jo normalaus vystymosi $[13,15]$. Labai svarbu išsiaiškinti, kokias problemas sprendžia jautrių maistui vaikų tèvai, siekiant pagerinti šeimų gyvenimo kokybę, vengiant alergizuojančių medžiagų bei užtikrinant visavertę vaiko mitybą.

Darbo tikslas: ištirti ikimokyklines įstaigas Kauno mieste lankančių vaikų jautrumo maistui dažnị, alergizuojančius maisto produktus bei tėvų nuomonę apie vaikų maisto alergijas bei šeimos gyvenimo kokybès pokyčius.

\section{Kontingentas ir tyrimo metodai}

Momentinis epidemiologinis tyrimas atliktas Kauno miesto ikimokyklinio ugdymo ịstaigose 2015-2016 metais. Istaigos buvo atrinktos taikant atsitiktinę lizdinę atranką. Iš Kauno miesto savivaldybès tinklapyje skelbiamo Kauno miesto ikimokyklinių ịstaigu sąrašo buvo atsitiktinai atrinkta 23 įstaigos. Tyrimui atlikti buvo gautas Kauno miesto švietimo ir ugdymo skyriaus vedejo leidimas bei Lietuvos sveikatos mokslu universiteto Bioetikos centro leidimas (Nr. BC-VC (M)-279). Tyrimui buvo sudaryta anketa, atsi- 
žvelgiant ị „EuroPrevall“" projekte naudotą klausimyną bei kitus klausimynus, nagrinejjančius jautrumo maistui problemas. Pagal Europos alergologų ir klinikinių imunologų akademijos priimtą alerginių ligų nomenklatūrą, literatūros duomenimis [7,9], taip pat noredami išvengti interpretavimo klaidų, alergiją maistui ir padidejusị nealerginị jautrumą maistui priskyrème padidejusiam jautrumui maistui (toliau jautrumas maistui) [16]. Pirmojoje klausimyno dalyje visi tyrime dalyvavę tèvai nurode savo ir vaiko sociodemografinius duomenis, tokius kaip lytis, amžius, išsilavinimas, gyvenamoji vieta. Antros dalies klausimai buvo skirti vaiku jautrumo maistui bei tẻvų žinioms apie ši sveikatos sutrikimą įvertinti. Buvo apklausti 1143 vaikų tèvai (atsako dažnis 86,4 proc.). Daugiausia ị anketos klausimus atsakinejjo vaikų mamos ( 82,4 proc.), ne téčiai - (17,6 proc.). Jauniausias respondentas buvo 19 metų, vyriausias -45 metų. Apklaustujų amžiaus vidurkis buvo $31,4 \pm 4,33 \mathrm{~m}$. Analizuojant tyrimo duomenis, respondentai buvo suskirstyti ị dvi amžiaus grupes: pirmai grupei priskirti tévai iki 33 metų imtinai, ị antrą grupę itraukti tevai 33 metų ir vyresni. Didžioji dalis $(68,1$ proc.) respondentų buvo igiję aukštaji išsilavinimą. Tyrime dalyvavo 584 mergaičių (51,1 proc.) ir 559 berniukų (48,9 proc.) tèvai. Vaikų amžius svyravo nuo vieneriu

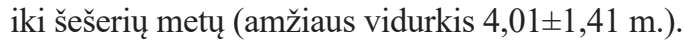

Duomenų vertinimui buvo naudota aprašomoji statistika. Kokybinių požymių tarpusavio priklausomumui vertinti buvo taikomas chi kvadrato $\left(\chi^{2}\right)$ kriterijus ir Fišerio (Fisher) tikslusis testas. Tẻvų žinių apie vaikų maisto sukeltą jautrumą sąsajos su tèvų išsilavinimu ir amžiumi buvo vertinamos naudojant logistinę regresiją, skaičiuojant galimybių (šansų) santykị ir 95 proc. pasikliautinị intervalą (PI). Naudotas statistinio reikšmingumo lygmuo $\alpha=0,05$; skirtumas buvo statistiškai reikšmingas, kai $\mathrm{p}<0,05$.

\section{Rezultatai}

Tèvų nuomone, jautrūs maistui buvo 174 (15,2 proc.) tirti vaikai, iš jų 98 (17,5 proc.) berniukai ir 76 (13,0 proc.) mergaitès. Toliau darbe buvo nagrinèti bei vertinti tik tie atvejai, kurių tèvai nurodè, jog jų vaikas yra jautrus maistui.

Tẻvų išsakyta nuomonè apie vaikų jautrumą tam tikriems maisto produktams pateikta 1 paveiksle. Tèvų nuomone, dažniausiai jautrumą maistui ikimokyklinio amžiaus vaikams sukelia šie maisto produktai: pienas, šokoladas, citrusiniai vaisiai ir kiaušiniai. Daugiau nei pusè berniukų yra alergiški pienui ( 54,1 proc.), o mergaitès šokoladui $(61,8$ proc.). Apklausos duomenimis, mažiausiai vaikai yra alergiški daržovėms ir grūdinès kilmès produktams. Apie 5 proc. respondentų nežinojo, kokiam

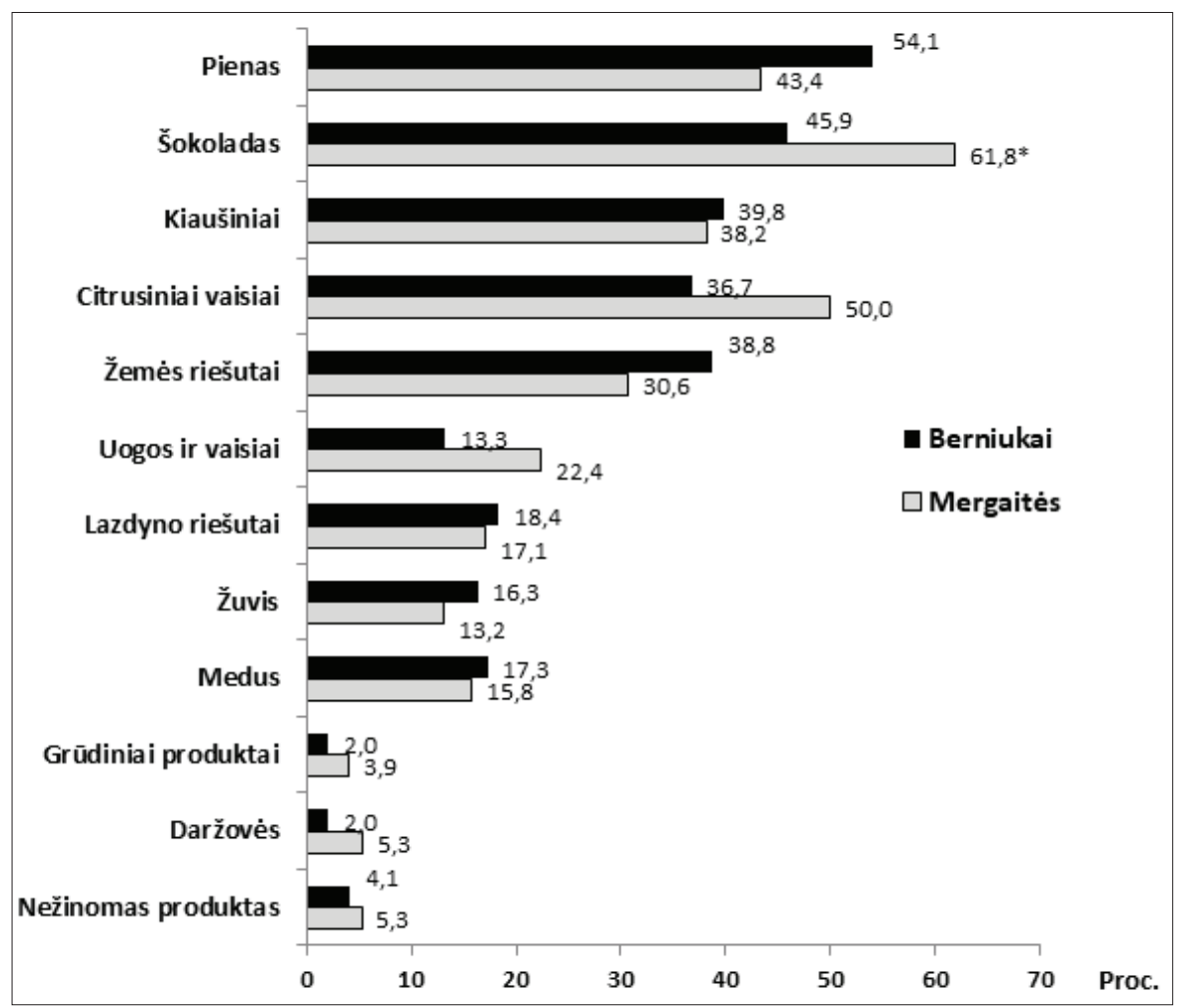

1 pav. Respondentų teigiamų atsakymų ị klausimą „Kokiam maisto produktui ar jų grupei alergiškas (jautrus) Jūsų vaikas?“ dažnis (proc.)

${ }^{*} p<0,05$ lyginant su berniuku grupe.

1 lentelè. Tèvų nuomone, dažniausiai jautrumą maistui sukeliančių maisto produktų skaičius.

\begin{tabular}{|l|c|c|}
\hline $\begin{array}{l}\text { Maisto produktų } \\
\text { (maisto grupių) skaičius }\end{array}$ & $\begin{array}{c}\text { Berniukai } \\
\mathbf{N = 9 8}\end{array}$ & $\begin{array}{c}\text { Mergaitès } \\
\mathbf{N = 7 6}\end{array}$ \\
\cline { 2 - 3 } & $\mathrm{n}$ (proc.) & $\mathrm{n}$ (proc.) \\
\hline 1 & $26(26,5)$ & $27(35,5)$ \\
\hline $2-3$ & $38(38,8)$ & $21(27,6)$ \\
\hline $4-5$ & $18(18,4)$ & $15(19,7)$ \\
\hline 6 ir daugiau & $12(12,2)$ & $9(11,9)$ \\
\hline $\begin{array}{l}\text { Nežino kokiems produk- } \\
\text { tams alergiškas }\end{array}$ & $4(4,1)$ & $4(5,3)$ \\
\hline
\end{tabular}


maisto produktui yra jautrus jų vaikas (1 pav.).

Tyrimo rezultatai parodè, kad vaikai gali būti jautrūs ne tik vienam, bet ir keliems maisto produktams ar jų grupėms (1 lentelè). Tẻvų nuomone, berniukai 1,4 karto dažniau buvo jautrūs 2-3 maisto produktams, lyginant su mergaitėmis $(\mathrm{p}>0,05)$. Mergaičių tevvai pažymejjo, kad jos dažniausiai buvo jautrios vienam maisto produktui $(35,5$ proc.). Tačiau 6 ir daugiau maisto produktų buvo jautrūs beveik vienoda dalis berniukų bei mergaičių, atitinkamai 12,2 proc. ir 11,9 proc.

Toliau buvo analizuota, kokiems maisto produktams dažniausiai jautrūs vaikai, atsižvelgiant $i$ jiems nepageidaujamas reakcijas sukeliančių maisto produktų skaičių (2 pav.). Beveik pusei berniukų (46,2 proc.), jautrių vienam maisto produktui ar jų grupei, pasireiškė jautrumas pienui, rečiau šokoladui (23,0 proc.) ir kiaušiniams (15,4 proc.). Mergaitès jautrios vienam maisto produktui, daugiausia netoleravo citrusinių vaisių (25,9 proc.), rečiau pieno (18,6 proc.) ar šokolado (18,5 proc.). Vaikams, įsijautrinusiems 2-3 maisto produktams, pirmoje vietoje buvo jautrumas

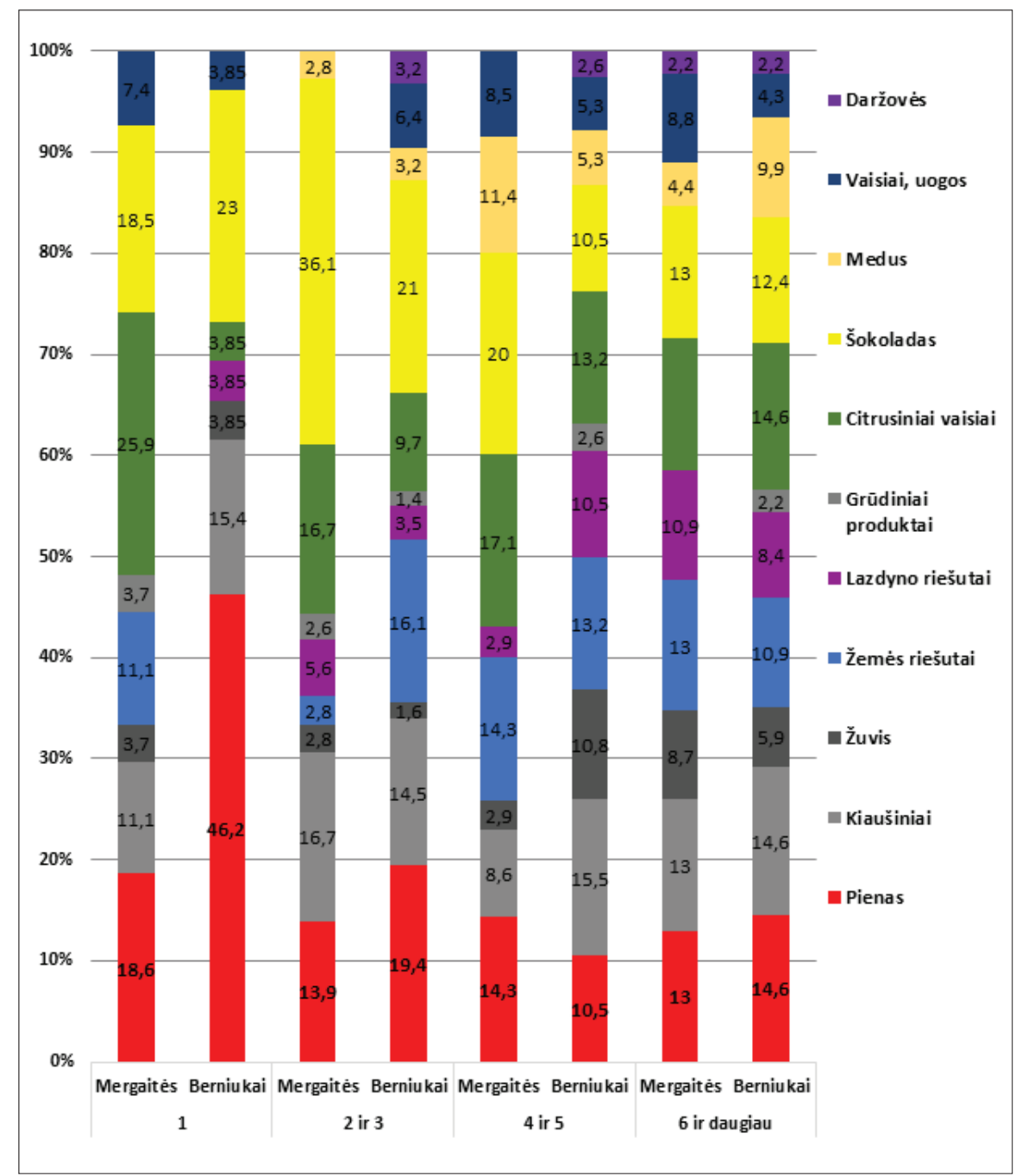

2 pav. Vaikų netoleruojamų maisto produktų skirstinys (proc.) jautrumą sukeliančių produktų skaičiaus atžvilgiu. šokoladui - jo negalèjo valgyti kiek daugiau negu trečdalis mergaičių $(36,1$ proc.) ir penktadalis berniukų ( 21,0 proc.). Nuo šių nedaug atsiliko citrusiniai vaisiai ir kiaušiniai, kurie daugiau vargino mergaites, ir pieno produktai bei žemès riešutai, kuriems dažniau jautrūs berniukai. Vaikams, turintiems alergiją 4-5 maisto produktams, daugiausia jautrumą maistui sukelia šokoladas, citrusiniai vaisiai, kiaušiniai, žemès riešutai (2 pav.).

Respondentų buvo paklausta, kas nustate jautrumą maistui jų vaikams. Tèvai pažymėjo, kad dažniausiai jų vaikams jautrumą maistui diagnozavo alergologas $(47,2$ proc.) bei šeimos gydytojas (41,8 proc.). Vertinant dažniausiai pasireiškusių simptomų dažni jautriems maistui vaikams buvo nustatyta, kad vaikus dažniausiai vargino odos simptomai, tokie kaip egzema, dilgèlinè, odos niežulys, odos patinimas. Šie simptomai užèmè pirmą vietą tarp tirtujų, kurie nurodė vaiko alergiją maistui, ir jie vargino apie 79,3 proc. jautrių maistui vaikų (80,6 proc. berniukų ir 77,7 proc. mergaičių). Kitos pažymètos reakcijos į maistą buvo sloga, čiaudulys, užburkusi nosis (atitinkamai 41,8 proc. berniukų ir 31,6 proc. mergaičių). Retesni nusiskundimai buvo burnos, lūpų, akių niežulys, paraudimas bei pilvo skausmai. Tačiau galvos svaigimo, maisto sukelto anafilaksinio šoko tèvai nenurodè.

Tyrimo metu respondentams buvo pateiktas klausimas; „Kokios itakos šeimos gyvenimo kokybei turi tai, jog Jūsų vaikas yra jautrus (alergiškas) maistui?"“ Paaiškejjo, kad pastangos išlaikyti maisto produktų ìvairovę vaiko racione ir tinkamiausio gydymo būdo ieškojimas kèlè daugiausia rūpesčių vaikų tèvams (82,2 proc.). Dar vie- 
nas, jautrių maistui vaikų tėvų buitị lemiantis veiksnys buvo nuolatinis maisto produktų etikečių skaitymas ( 81,0 proc.) bei maisto davinio, $\mathfrak{i}$ kurio sudèti įeina daugiau negu vienas produktas, pasirinkimas ( 71,8 proc.). Taip pat respondentai nurodè, jog, siekdami apsaugoti vaiką nuo alergizuojančiu medžiagų (69,5 proc.), keitè visos šeimos mitybą, bei patyre sunkumus planuodami atostogas, keliones, rinkdamiesi poilsio vietas (54,0 proc.).

Vertinant tèvų žinias apie jautrumą maistui, didžioji dalis manè, kad jautrumą maistui sąlygojo genetiniai veiksniai. Šị veiksnị nurodè 68,9 proc. aukštajị išsilavinimą igijusių tèvų ir 51,7 proc. neigijusių aukštojo išsilavinimo $(p<0,05)$. Statistiškai reikšmingai daugiau žinių apie alergiją maistui ir anafilaksinio šoko galimybę turejjo aukštaji išsilavinimą igiję respondentai (atitinkamai $\breve{S} S=2,73$ (95 proc. PI $1,25-6,31)$ ir $\breve{S} S=2,83$ (95 proc. PI 1,98-4,95)). Statistiškai reikšmingai daugiau žinojusių, kas yra anafilaksinis šokas, priklausė jaunesnei amžiaus grupei (19-33 m.) $\left(\chi^{2}=5,17\right.$, $1 l s=1, \mathrm{p}=0,025)$ S S $=1,81$ (95 proc. PI 1,19-2,97). Dauguma tèvų mané, jog pagrindiniai maisto alergenai yra citrusiniai vaisiai (74,7 proc.), šokoladas ( 69,5 proc.), kiaušiniai (52,3 proc.) ir pienas ( 47,7 proc.). Klaidingai tèvų buvo manyta, kad dažniausiai vaikai tampa jautrūs maisto priedams (dažikliams, konservantams, kvapiosioms medžiagoms, skonio stiprikliams). Taip manè 76,4 proc. aukštajị išsilavinimą igijusių tèvų ir 64,9 proc. žemesnį išsilavinimą turinčių tèvų, nors ši jautrumo maistui priežastis nė vienam tirtujų nebuvo nustatyta. Pasidomejjus, iš kur respondentai norètu gauti papildomos informacijos apie jautrumą maisto produktams, didžioji dalis tèvų ( 90,8 proc.) nurodè, kad šios informacijos norètų daugiau gauti iš gydytojo. Taip pat trečdalis $(34,5$ proc.) šiu tėvų norètų informacijos papildomai gauti iš dirbančio darželyje visuomenès sveikatos specialisto.

\section{Rezultatụ aptarimas}

Mūsų atlikto tyrimo rezultatai parode, jog jautrumo maistui dažnis tirtuose Kauno vaikų darželiuose yra 15,2 procentai. Tokie rezultatai buvo panašūs ị ankstesnius „EuroPrevall“ atliktų apklausų duomenis. Juose nuo 5 iki 35 proc. tèvų mano, jog jų vaikai yra jautrūs maistui [1]. Kitose pasaulio šalyse atlikti tyrimai rodo, jog šie skaičiai yra labai skirtingi: nuo itin didelio jautrumo dažnio Mongolijoje bei Šiaurès Kinijoje - 38,7 proc., Gruzijoje - 15,7 proc., Čileje - 13 proc., Meksikoje - 10,6 proc. iki ypač žemo - Honkonge 4,8 proc. [2-6]. Skirtumus gali lemti skirtingi mitybos ịpročiai bei vartojami maisto produktai. Mūsų atlikto tyrimo duomenimis, maistui jautresni buvo berniukai, nors skirtumas nebuvo statistiškai reikšmingas. Lietuvoje jautrių maistui vaikų, lankančių ikimokyklines įstaigas, dažnis mažai tyrinètas, ji aptarsime remdamiesi panašiomis vykdytomis apklausomis.
Lietuvoje apklausus vyresnius vaikus, buvo gauta, kad berniukų sergamumas jautrumu maistui yra neženkliai didesnis. Vilniaus mieste atlikto tyrimo metu apklausti 4333 pradinių mokyklų 1-4 klasių mokiniai. Berniukams jautrumas maistui buvo pasireiškęs dažniau nei mergaitèms (18,1 ir 14,8 proc. atitinkamai) [7]. Mūsų tyrimo duomenimis, vaikai daugiausia buvo jautrūs pienui ir jo produktams, šokoladui, citrusiniams vaisiams ir kiaušiniams.

Vilniuje atlikto pradinių klasių moksleivių tyrimo duomenimis, buvo sudarytas vaikus alergizuojančių maisto produktų sąrašas: vaisiai ir uogos $-24,6$ proc., pienas ir jo produktai - 19,4 proc., šokoladas - 10,9 proc., kiaušiniai - 7,4 proc., rečiau - daržovès, riešutai, mèsa, žuvis, vėžiagyviai [18]. Švedų mokslininkai apklausè 1139 ịvairaus amžiaus respondentus iš Šiaurès Europos šalių: Rusijos, Lietuvos ir Estijos. Nustatyta, kad šio regiono gyventojai daugiausia buvo jautrūs citrusiniams vaisiams, šokoladui, medui, obuoliams, riešutams, braškèms, žuviai, pomidorams, kiaušiniams ir pienui. Šių autorių taip pat nurodyta, jog egzistuoja skirtumai tarp šalių arba jų grupių, nulemti mitybos ypatumų [17]. Tai labai svarbu, nes kuo daugiau maisto produktų alergizuoja vaiką, tuo sunkiau gali būti tèvams organizuoti vaikų mitybą ir išlaikyti maisto davinio ịvairovę [15].

Mūsų atlikto tyrimo duomenimis, dažniausiai vaikams pasireiškè odos reakcijos: egzema dilgèlinè, odos niežulys, odos patinimas. Šie simptomai užèmé pirmą vietą tarp tirtujų, kurie nurodè vaiko jautrumą maistui, ir minètieji simptomai vargino daugiau negu du trečdalius visų jautriu maistui respondentų. Atliekant ankstesnius tyrimus, apklausus 4333 Vilniaus pradinių mokyklų 1-4 klasių mokinius, vyravo odos reakcijos ị maistą, jų buvo 62,7 proc., po jų sekè skausmingos, paraudusios ar ašarojančios akys $(23,5$ proc.) [18]. Nors mūsų tyrimo duomenimis, berniukus šiek tiek dažniau nei mergaites vargino odos simptomai, tačiau, kaip ir Vilniaus pradinése mokyklose, reikšmingų skirtumų tarp berniukų ir mergaičiu nebuvo nustatyta $[7,18]$.

Tẻvų nuomone, jautrumą maistui gali sąlygoti genetiniai veiksniai. Tą patvirtina literatūros duomenys. Alerginèmis ligomis dažniau serga asmenys, kurių pirmos eilès giminès serga ar sirgo alerginėmis ligomis $[8,14]$. Tačiau daugelis alerginių ligų siejamos taip pat ir su aplinkos užterštumu [19], ko nenurodè nè vienas respondentas.

Šeimos, auginančios vaikus, turinčius jautrumą maistui, susiduria su kasdieninėmis problemomis apsiperkant maisto parduotuvėse, gaminant maistą namuose, o ypač daug ittampos kelia vaikų maitinimas restoranuose bei kitose visuomeninio maitinimo įstaigose [11-15]. Šias problemas nurodè ir mūsų tyrime dalyvavę respondentai. Visgi mūsų atlikto tyrimo duomenys rodo, jog viena aktualesnių problemų yra 
taip pat tinkamiausio gydymo būdo paieška, kas nèra aktualu daugelio šalių respondentams.

Apibendrinant galima teigti, jog vaikų jautrumas maistui yra dažna ir svarbi problema, todèl būtina tęsti maisto alergijų tyrimus, kad būtų ịvertinta alergizuojančių maisto produktų kaita, jų sukeliamų reakcijų pobūdis, kas padètų sukurti veiksmingas priemones valdyti maisto alergijas bei šeimų, auginančių alergiškus vaikus, gyvenimo kokybei gerinti.

\section{Išvados}

Nustatyta, kad 15,2 proc. Kauno ikimokyklines įstaigas lankančių vaikų buvo jautrūs maistui. Dažniausiai jautrumą maistui sukèlè pienas, šokoladas, citrusiniai vaisiai. Tèvų nuomone, berniukai dažniau buvo jautrūs 2-3 produktams, mergaitės - vienam produktui.

Maistui jautrius vaikus dažniausiai vargino odos simptomai, tokie kaip egzema, dilgèlinè, odos niežulys. Didžiajai daliai respondentų vaikų jautrumą maistui nustatė alergologas bei šeimos gydytojas.

Statistiškai reikšmingai daugiau žinių apie alergijos priežastis bei alergijos simptomus turèjo aukštąị išsilavinimą igiję tirtujų vaikų tėvai. Vaikų jautrumas maistui, siekimas užtikrinti tinkamą mitybą bei gydymą lèmé didžiosios dalies respondentų šeimos gyvenimo kokybę ( 82,2 proc.).

\section{Literatūra}

1. McBride D, Keil T, Grabenhenrich L, Dubakiene R, Drasutiene G, Fiocchi A. et al. The EuroPrevall birth cohort study on food allergy: baseline characteristics of 12,000 newborns and their families from nine European countries. Pediatr Allergy Immunol 2012;23(3):230-9. https://doi.org/10.1111/j.1399-3038.2011.01254.x

2. Bedolla-Pulido TR, Bedolla-Barajas M, Morales-Romero J, Bedolla-Pulido TI, Domínguez-García MV, Hernández-Colín DD, Flores-Merino MV. Self-reported hypersensitivity and allergy to foods amongst Mexican adolescents: prevalence and associated factors. Allergol Immunopathol (Madr) 2018 Nov 29. doi: 10.1016/j.aller.2018.09.004.

https://doi.org/10.1016/j.aller.2018.09.004

3. Wang XY, Zhuang Y, Ma TT, Zhang B, Wang XY. Prevalence of self-reported food allergy in six regions of Inner Mongolia, Northern China: a population-based survey. Med Sci Monit 2018;24:1902-11. https://doi.org/10.12659/MSM.908365

4. Lomidze N, Gotua M. Prevalence of self-reported food allergy in different age groups of Georgian population. Georgian Med News 2015;241:40-4.

5. Hoyos-Bachiloglu R, Ivanovic-Zuvic D, Álvarez J, Linn K, Thöne N, de los Ángeles Paul M, Borzutzky A. Prevalence of parent-reported immediate hypersensitivity food allergy in
Chilean school-aged children. Allergol Immunopathol (Madr) 2014;42(6):527-32.

https://doi.org/10.1016/j.aller.2013.09.006

6. Ho MH, Lee SL, Wong WH, Ip P, Lau YL. Prevalence of selfreported food allergy in Hong Kong children and teens a population survey. Asian Pac J Allergy Immunol 2012;30(4):275-84.

7. Kavaliūnas A., Šurkienė G., Dubakienė R., Stukas R. Padidejusio jautrumo maisto produktams sukeliamų negalavimų pobūdis ir paplitimas tarp Vilniaus miesto gyventojų. Medicinos teorija ir praktika, 2012;18(1):10-7.

8. Nwaru BI, Hickstein L, Panesar SS, Roberts G, Muraro A, Sheikh A. EAACI food allergy and anaphylaxis guidelines group. Prevalence of common food allergies in Europe: a systematic review and metaanalysis. Allergy 2014;69(8):992-1007. https://doi.org/10.1111/all.12423

9. Kavaliūnas A., Šurkienė G., Dubakienė R., Stukas R. Alergijos maistui epidemiologija: rizikos veiksniai, paplitimas, reikšmè. Visuomenès sveikata, 2010;51(4):35-44.

10. Burney PG, Potts J, Kummeling I, Mills EN, Clausen M, Dubakiene R, Barreales L. et al. The prevalence and distribution of food sensitization in European adults. Allergy 2014;69(3):36571.

https://doi.org/10.1111/all.12341

11. Ostblom E, Egmar AC, Gardulf A, Lilja G, Wickman M. The impact of food hypersensitivity reported in 9 year old children by their parents on health-related quality of life. Allergy 2008: 63: 211-8.

https://doi.org/10.1111/j.1398-9995.2007.01559.x

12. Bollinger ME, Dahlquist LM, Mudd K, Sonntag C, Dillinger L, McKenna K. The impact of food allergy on the daily activities of children and their families. Ann Allergy Asthma Immunol 2006;96(3):415-21.

https://doi.org/10.1016/S1081-1206(10)60908-8

13. Alanne S, Laitinen K, Söderlund R, Paavilainen E. Mothers' perceptions of factors affecting their abilities to care for infants with allergy. J Clin Nurs 2012;21(1-2):170-9.

https://doi.org/10.1111/j.1365-2702.2010.03587.x

14. Walkner M, Warren C, Gupta RS. Quality of life in food allergy patients and their families. Pediatr Clin North Am 2015; 62(6):1453-61.

https://doi.org/10.1016/j.pcl.2015.07.003

15. Rouf K, White L, Evans K. A qualitative investigation into the maternal experience of having a young child with severe food allergy. Clin Child Psychol Psychiatry 2012; 17(1):49-64. https://doi.org/10.1177/1359104511415636

16. Dubakienè R. Lietuviški alergologijos terminai. Botanica Lithuanica. 2005;Suppl.8: 47-50.

17. Eriksson NE, Möller C, Werner S, Magnusson J, Bengtsson U, Zolubas M. Self-reported food hypersensitivity in Sweden, Denmark, Estonia, Lithuania, and Russia. J Investig Allergol Clin Immunol 2004;14(1):70-9. 
18. Kavaliūnas A, Šurkienė G, Dubakienė R, Stukas R, Žagminas $\mathrm{K}$, Šaulytė J ir kt. EuroPrevall survey on prevalence and pattern of self-reported adverse reactions to food and food allergies among primary schoolchildren in Vilnius, Lithuania. Medicina, 2012; 48(5):265-71.

https://doi.org/10.3390/medicina48050038

19. Gilles S, Akdis C, Lauener R, Schmid-Grendelmeier P, Bieber T, Schäppi G, Traidl-Hoffmann C. The role of environmental factors in allergy: a critical reappraisal. Exp Dermatol 2018; 27(11):1193-200.

https://doi.org/10.1111/exd.13769

\section{EVALUATION OF PARENTS OPINION AND KNOWLEDGE ABOUT FOOD SENSITIVITY OF CHILDREN ATTENDING KAUNAS PRESCHOOL INSTITUTIONS}

R.Ustinavičienė, D.Lukšienė, R.Radišauskas, L.Škėmienė

Key words: sensitivity to food, food allergens, parents knowledge about food sensitivity, quality of family life.

Summary

Food products may cause various undesirable reactions, which are called increased sensitivity to food products. The objective of this study was to evaluate the prevalence of sensitivity to food among preschool pupils in Kaunas as well as their parent's opinion and knowledge of this phenomenon. 1143 parents participated in the survey. It was found that frequency of sensitivity to food products among preschool pupils was $15.2 \%(\mathrm{n}=174)$, among which $98(17.5 \%)$ were boys and $76(13.0 \%)$ were girls. Girls were most commonly sensitive to chocolate $(61.8 \%)$, citrus fruit $(50.0 \%)$ and milk (43.4\%); boys were sensitive to milk (54.1\%), chocolate (45.9\%) and eggs (43.4\%). Sensitivity to food most commonly manifested as skin allergic reactions ( $80.6 \%$ boys and $77.7 \%$ girls) as well as allergic rhinitis ( $41.8 \%$ boys and $31.6 \%$ girls). According to the pupils' parents, food allergies are caused by genetic factors, diet and environmental pollution. Respondents with higher education possessed statistically significantly more information about food allergies and possibility of anaphylactic shock $(\mathrm{OR}=2.73$ $(95 \%$ CI: $1.25-6.31)$ and OR $=2.83$ (95\% CI: $1.98-4.95)$ respectively). Children's sensitivity to food affected most of the respondents' quality of life (82.2\%) while seeking to ensure appropriate diet and treatment.

Correspondence to: ruta.ustinaviciene@1smuni.1t

Gauta 2019-01-07

\section{KVIEČIAME PRENUMERUOTI "SVEIKATOS MOKSLŲ" ŽURNALĄ 2019 METAIS!}

Žurnalas "Sveikatos mokslai" (Index Copernicus, EBSCO host (Academic Search Complete), Gale (Academic OneFile), ProQuest (Ulrich's, Summon), Australia (ERA) 2012 Journal List (ERA ID 34962) skirtas visų specialybių gydytojams, slaugytojams ir kitiems specialistams, spausdina mokslinius straipsnius lietuvių, anglų kalbomis. Reikalavimai straipsniams atitinka mokslo leidiniams keliamus reikalavimus. Žurnalas kioskuose neparduodamas. Žurnalą, kuris leidžiamas kartą per du mėnesius, galima užsiprenumeruoti visuose Lietuvos pašto skyriuose, taip pat internetu: www.prenumeruok.lt Prenumeratos kaina nesikeičia: visiems metams - 36 EUR, šešiems mẻnesiams - 18 EUR, keturiems mėnesiams - 12 EUR, dviem mėnesiams - 6 EUR. Prenumeratos kodas: 5348. Žurnalo autoriams straipsnių spausdinimas mokamas. 